\title{
TRANSLATION OF RHETORIC IN ARABIC PREPOSITION IN THE TEXT OF AL-QUR'AN
}

\author{
Azman Che Mat ${ }^{1}$; Ahmad Zulfadhli bin Nokman ${ }^{2}$ \\ ${ }^{1,2}$ Academy of Language Studies, Universiti Teknologi Mara \\ Kampus Dungun, Terengganu, Malaysia \\ 1azman531@tganu.uitm.edu.my/azmanchemat@yahoo.com
}

\begin{abstract}
Preposition was a word that completes the meaning of the verb and noun in the sentence structure of Arabic. The use of prepositions in Arabic was truly significant in understanding the Arabic text, especially holy texts. The question was why prepositions were used in sentences such, whereas the other joints could also give the same meaning? Article presented an analysis of syntax-semantics of prepositions في Fi and فلى Ala in alQuran al-Karim across science of Arabic rhetoric (Balagha). Data were restricted to partial phrase في الضال and ever discussed by Ibn Athir. There are 29 places in the Quran that mention فلى الهاى 6 and points for Critical analysis based on the discipline of linguistics is expected to expose the use of prepositions in Arabic from the precision and beauty of the Arabic language itself. Summary of the study suggest that research on elements of the rhetoric says that other reasonable tasks highlighted in subsequent studies.
\end{abstract}

Keywords: prepositions, syntax-semantics, rhetoric, precision

\section{INTRODUCTION}

In the Arabic language, the word that connects words before and after is called harf al-Jarr. In the Malay and English language, they are called prepositions. The prepositions are not able to stand alone as a complete sentence. Its function is to complete the meaning (see Ibn Jinni, 1988; Ibn Faris, 1998; al-Suyuti, 1998; al-Suhayli, 1992; al-Zajjaji, 1992) in verbal sentences or nominal sentences. In a complete sentence structure, preposition usually comes as an elaboration to the nominal phrases or verbal phrases. In the discourse of the Arabic language, the use of prepositions gives various effects of meaning explicitly and implicitly. Thus Arabic scholars such as Al-Harawi (1993), al-Muradi (1992) and Hassan (1982) have discussed in detail the meaning given by any of preposition in Arabic when used in sentences and discourses.

In-depth discussion of this has given every Arabic preposition an implicit meaning based on its position within a paragraph. Therefore, a preposition can have more than its original meaning, despite the fact that it only works when the meaning is in the structure of the sentence. Previously there have been researchers who mentioned the importance and the need of understanding the Arabic preposition for translation purposes. The preposition in Arab language has its own uniqueness, especially when it comes to the sacred texts and the texts which are important in the field of thought and philosophy. Even so, there is still dimension of prepositions that have not been fully dismantled in order to strengthen the Arabic translation in the Malay language. 


\section{METHODS}

An earlier study of prepositions and their use in al-Qur'an al-Karim has motivated researcher to examine in depth the use of prepositions. According to the study by Kamarul Shukeri Mat Teh (2005), the meaning of prepositions contributes to the production of legal jurisprudence such as the use of the preposition 4 in paragraph $\{\ldots$.... meaning of prepositions in the verses of the Qur'an, the jurists will produce their views based on the understood meaning of prepositions used in the respective text. The similar discussions from a legal point of fiqh by Hasanah Abu Khafiz (2009) related to the use of prepositions فـ versus regarding the eligible recipients to receive zakat. The difference in the use of prepositions also has major implications for the receiving of Zakat and mentioned the right to use it among recipients.

The study conducted by Azman Che Mat (2014a) has suggested a model translation prepositions in general. In this study, the technique for preposition translation is described to help translators when they are facing a preposition phrase in Arabic discourse. However, these technical aspects may not fully able in the certain condition to ensure the translators to produce an effective translation in their works. If the preposition can influence scholars for the establishment of fiqh, then certainly in the field of rhetoric, the preposition also has its own beauty to be discovered especially in the al-Qur'an. The science of rhetoric (al-Balagha) is an important branch of Arabic studies. This science aims to maintain the intended meaning of speech from an error and to distinguish eloquent speech to the rest (Yahya Murād as cited in al-Hāshimi, 2005). In short, the science of rhetoric reveals the beauty of Arabic language composition from the election of the word until the formation of discourse.

Based on the study, the researcher found that Arabic scholars have discussed the use of

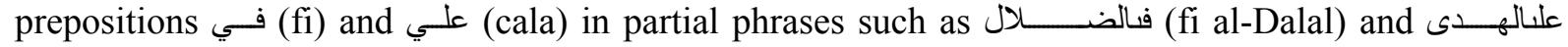
(cala al-Huda). Why this combination of the preposition is consistent in al-Qur'an? Is Malay translation impact as beautiful in Arabic? To answer this question, the method of discourse analysis was applied where data from the al-Qur'an were collected and disbursed for the purposes of descriptive analysis. This approach takes into consideration the aspects of semantics and also Malay translation of "Tafsir Pimpinan Ar-Rahman kepada Pengertian Al-Quran" by Abdullah Basmeih (1995), the prominent translator of al-Qur'an into the Malay language.

\section{RESULTS AND DISCUSSIONS}

After reading some references, the researcher has determined related data for this study. The original text (Al-Quran) and translation of Al-Quran were compared in parallel. The data collected from Al-Qur'an Al-Karim is listed in order by surah. It altogether describes in the table.

Table Translation of $F i$ and ${ }^{c} A l a$

\begin{tabular}{ccccc}
\hline Partial Phrase & ع على الهدى & \multicolumn{1}{c}{} \\
\hline Translation & Dalam (in) & Atas (On) & Mendapat (Have/get) & Dari (of/from) \\
Total & $29 / 29$ & $4 / 6$ & $1 / 6$ & $1 / 6$ \\
Percentage & $100 \%$ & $66 \%$ & $17 \%$ & $17 \%$ \\
\hline
\end{tabular}

Based on the table, it was found that the translation is with the preposition "in" as a whole (100\%). While preposition على is translated to "above" (66\%), "get" (17\%), and "from" (17\%). 
Based on data collected for the partial phrase الضــــــالفيـا, it is noted that translators use the literal approach in translation. The literal meaning commonly refers to the translation of Arabic preposition is matched directly word to word with prepositions in Malay (Mohd Helmi Abdullah, 2008; Muhammad Fauzi Jumingan, 2001). According to Arabic grammar, preposition في refers to a description, namely the place or time (al-Muradi, 2002). For example, النقودفيالجي , it means the money in the pocket (Duit ada (di) dalam pocket), and وصلمحمدفيالدســ, it means Muhammad arrived in the evening (Muhammad sampai pada waktu petang). In the example above, the translator directly chooses preposition "dalam" (in) to describe the place in the Malay language.

Based on the Malay language grammar, "dalam" is a preposition, meaning a scope that does not have space or distance (Nik Safiah et al., 2008). The use of "dalam" here aims to clarify something in that particular area associated with an object such as Ahmad's pencils are in a bag. However, the partial phrase of this verse, the word الضــالد refers to the abstract meaning (intangible). This word comes from the root word "ضـل that has meaning vanished, lost, damaged, destroyed, wasted (Mustafa et al., 1989). Therefore the illustration of the place or the time for this word is described only mentally. The thing could not be seen with the naked eye as a pen that is in the bag and so on.

Translation is done in the Malay language is also similar when referring to the noun astray or wrong path or in a state of insanity. According to Kamus Dewan, the meaning of astray concerns the lost (trips), confusion, and mistake (Teuku Iskandar \& Baharuddin Zainal, 2000). The selection of prepositional phrase "in astray" refers to abstract things (intangible) is equivalent to the original source of the Arabic language.

Regarding rhetoric aspect, the partial phrase of فيالضـ refers to the "internal" situation of astray. It is portrait as if "when someone is in error/astray," he faced some circumstances, namely: (1) difficult for him out, (2) he always stuck in that situation, (3) unable to identify circumstances beyond,

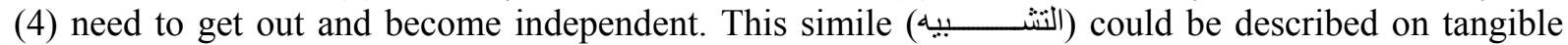
things such as a thing which is confined will face the above situation. In rhetoric science, the simile is a prominent part of speech which functioning to express an eloquence meaning in discourse (alHashimi, 2005). Therefore anyone who is found in astray faces similar circumstances as an imprisoned man in a low and dark cage (al-Hilali, 1986).

However, in this simile not all its components are used. Three of simile components are not used namely the linked to the simile features and the simile elements. In a rhetorical perspective, less word used to express a meaning but yet has a strong impact is better than a long one, but has a less impact, as a say خير الكلام ما قل و دل. According to 'Ali Jarim and Mustafa Amin (1951), such simile that does not mention the simile features and the simile elements in discourse is called as "al-Tashbih alMu'akkad al-Mujmal." Figure 1 presents a description of the simile original structure with all its components.

1. The Linked 2. The Linked to 3. The Simile Feature 4. The Simile Element

\begin{tabular}{|c|c|c|c|}
\hline Mushabbah & Mushabbah bihi & Wajh al-Shabh & Adah al-tashbih \\
\hline قي الضشلال & في الفجن المظلـم & 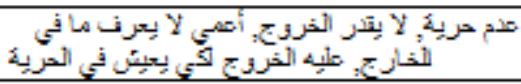 & متل/ك/كأن \\
\hline $\mathbf{v}$ & $\mathrm{x}$ & $\mathrm{x}$ & $x$ \\
\hline
\end{tabular}

Figure 1 Simile in Rhetoric Science for الضلال في 
Besides that, the partial phrase of على الهذى in this data was translated into two approaches, direct translation and indirect translation. Direct translation in this article means literal translation where each word is directly translated into target language based on lexical meaning. Four out of six data were identified as categorized into direct translation. In Arabic, preposition على refer to 'on' or 'highness' (al-Muradi 1992: 472).

In Malay language, literal translation for على is 'atas' / 'di atas' (on / above) (Azman, 2014b; Helmi, 2008; Muhammad Fauzi, 2001). 'Atas' in the Malay language is not the preposition, but called as direction noun which normally used together with the preposition to demonstrate direction and stream (Nik Safiah et al., 2008). Whereby for translation that using the preposition "dari", namely "of guidance" for translation على is not precisely because the context of the verse to mean comparison. Thus the selection of the preposition "daripada" for translation of cala is proposed. This is because the comparison is part of the meaning of cala (al-Muradi, 1992). While indirect translation at the partial phrases with cala is translated as "tetap" (consistent) without using any prepositions. In Malay, word "tetap" can be classified as a modal auxiliary. According to Nik Safiah, et al. (2008), a modal auxiliary describes a wide variety of auxiliary or a feeling of an act that be done.

From the science of rhetoric, the partial phrase على الهدى also be compared with someone who was on an agile horse (as a vehicle) (al-Hilali, 1986). Similar characteristics and properties happen when riding the vehicle means that a person can control his vehicle as quickly as possible and go wherever he wished. Some features of this similarity can be described as the following details: (1) Being in a high place (or truly respected), (2) being able to control the vehicle of his own volition, (3) can observe the situation and the atmosphere around, and (4) always control the situation and not being controlled. A more detailed illustration of the structure based on the science of rhetoric shows some basic components have been dropped. Abandonment these aspects, which are the linked to the simile feature and the simile element described in Figure 2.

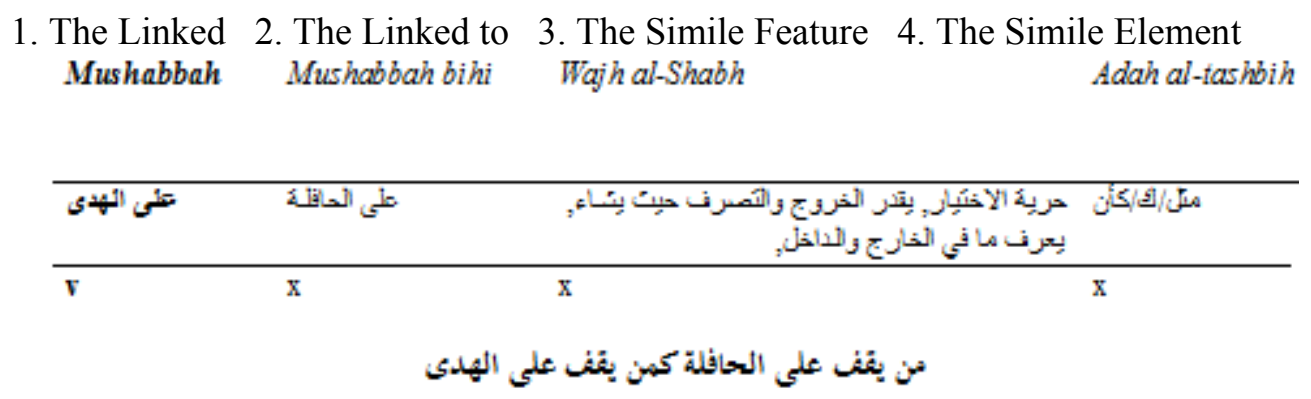

Figure 2 Simile in Rhetoric Science for على الهدى

\section{CONCLUSIONS}

In conclusion, the use of prepositions في في and partial phrases that previously discussed have a special beauty. In fact, this selection is very appropriate to the context of the story in the topics presented. This happened in Arabic prepositions used in the al-Qur'an. Then the translation process of partial phrase into the Malay language has forced translator to takesecureddirection to direct translation approach, which is known as the literal translation.

But the literal equivalence may only be viewed from the aspect of syntax and semantics. Is translation in the Malay language that is used to give the impression that match the rhetoric angle? Perhaps this is a translation problem that difficult to handle in the sacred text. 


\section{REFERENCES}

Al-Harawi, Ali Bin Muhammad. (1993). Kitab al-Azhiyyah fi Ilmi al-huruf. Damsyik: Majma alLughah al-Arabiyyah.

Al-Hashimi, al-Sayyid Ahmad. (2005). Jawahir al-Balaghah. Mesir: Mu'assasahal-Mukhtar.

Al-Hilali, Hadi ${ }^{c}$ Atiyyah Matar. (1986). Al-Huruf al- ${ }^{c}$ amilah Fi al-Qur'an al-Karim. Beirut: Alam alKutub.

Al-Muradi, al-Hasan Ibn Qasim. (1992). Al-Jana al-Dani fi Huruf al-Macani. Beirut: Dar al-Kutub al'Ilmiyyah.

Al-Suhayli, Abu al-Qasim Abd. Rahman bin ${ }^{c}$ Abdullah. (1992). Nata ’ij al-Fikr Fial-Nahw. Beirut: Dar al-Kutub al- ${ }^{\mathrm{C}}$ Ilmiyyah.

Al-Suyuti, Jalaluddin ${ }^{c}$ Abd al-Rahman Bin Abi Bakr. (1998). Ham $^{c}$ u al- Hawami ${ }^{c}$ fi Sharh Jam ${ }^{c} i$ alJawāmic. Lubnan: Dar al-Kutub al- ${ }^{-}$Ilmiyyah.

Azman Che Mat, (2014a). Model of Translating Preposition (MTP) of Arabic into Malay. Mediterranean Journal of Social Sciences, 5(23), 2420-2424.

Azman Che Mat, (2014b). Kata Sendi Nama Bahasa Arab: Terjemahannya ke Dalam Bahasa Melayu. Universiti Pendidikan Sultan Idris: Penerbit Universiti Pendidikan Sultan Idris.

${ }^{\mathrm{c}}$ Ali al-Jarim \& Mustafa Amin. (1951). Al-Balaghah al-Wadihah: al-Bayanwa al-Macaniwa al-Badīc . Mesir: Dar al-Macarif.

Hasanah Abd. Khafiz. (2009). Penterjemahan Kata Sendi "Fi" dan "Li" dalam Ayat Asnaf Zakat dan Implikasinya Terhadap Pengagihan Zakat kepada Asnaf tertentu di Malaysia. In Hasuria Che Omar \& Rokiah Awang (Eds). Kelestarian Bidang Terjemahan. Kuala Lumpur: Persatuan Penterjemah Malaysia.

Hassan, 'Awwād. (1982). Tanawub Huruf al-Jarr fi Lughat al-Qur'an. 'Amman: Dar al-Furqan.

Ibn Faris, Abu al-Husayn Ahmad. (1998). Al-Sahibi fi Fikh al-Lughah al- ${ }^{c}$ Arabiyyah wa Masa'iluha

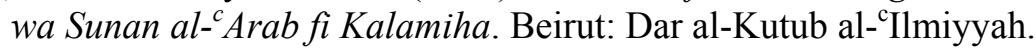

Kamarul Shukri bin Mat Teh. (2005). Tata bahasa Arab dan Pembinaan Hukum dari pada al- Qur'an. Kuala Lumpur: Penerbit Universiti Malaya.

Mohd Hilmi Abdullah. (2008). Teori \& Kaedah Penterjemahan Arab-Melayu. Kota Baharu: Pustaka Hilmi.

Muhammad Fauzi Jumingan. (2001). Penterjemahan kata sendi nama Arab-Melayu: suatu panduan. Jurnal Penterjemah, 1, 14-28.

Mustafa Ibrahim, ${ }^{\mathrm{c} A b d}$ al-Qadir, al-Zayyat \& al-Najjar. (1989). Al-Mu $u^{c}$ jam al-Wasit. Beirut: Dar 'Ihya' al-Turath al- ${ }^{\mathrm{c}}$ Arabi. 
Nik S. K., M. Onn, Hashim \& Hamid, A. (2008). Tata bahasa Dewan: Edisi Baharu. Kuala Lumpur: Dewan Bahasa dan Pustaka.

Sheikh Abdullah Basmeih. (1995). Tafsir Pimpinan ar-Rahman Kepada Pengertian Al-Qur'an. Jabatan Perdana Menteri: Bahagian Hal Ehwal Islam.

Teuku Iskandar \& Baharuddin Zainal. (2000). Kamus Dewan. Third Edition. Kuala Lumpur: Dewan Bahasa dan Pustaka. 